\title{
Asthma control in Latin America: the Asthma Insights and Reality in Latin America (AIRLA) survey
}

\author{
Hugo Neffen, ${ }^{1}$ Carlos Fritscher, ${ }^{2}$ Francisco Cuevas Schacht, ${ }^{3}$ \\ Gur Levy, ${ }^{4}$ Pascual Chiarella, ${ }^{5}$ Joan B. Soriano, ${ }^{6}$ and Daniel Mechali, ${ }^{7}$ \\ on behalf of the AIRLA Survey Group
}

Suggested citation: Neffen H, Fritscher C, Cuevas Schacht F, Levy G, Chiarella P, Soriano JB, et al. Asthma control in Latin America: the Asthma Insights and Reality in Latin America (AIRLA) survey. Rev Panam Salud Publica. 2005;17(3):191-7.

ABSTRACT Objectives. The aims of this survey were (1) to assess the quality of asthma treatment and control in Latin America, (2) to determine how closely asthma management guidelines are being followed, and (3) to assess perception, knowledge and attitudes related to asthma in Latin America.

Methods. We surveyed a household sample of 2184 adults or parents of children with asthma in 2003 in 11 countries in Latin America. Respondents were asked about healthcare utilization, symptom severity, activity limitations and medication use.

Results. Daytime asthma symptoms were reported by $56 \%$ of the respondents, and $51 \%$ reported being awakened by their asthma at night. More than half of those surveyed had been hospitalized, attended a hospital emergency service or made unscheduled emergency visits to other healthcare facilities for asthma during the previous year. Patient perception of asthma control did not match symptom severity, even in patients with severe persistent asthma, $44.7 \%$ of whom regarded their disease as being well or completely controlled. Only $2.4 \%$ (2.3\% adults and $2.6 \%$ children) met all criteria for asthma control. Although $37 \%$ reported treatment with prescription medications, only $6 \%$ were using inhaled corticosteroids. Most adults (79\%) and children (68\%) in this survey reported that asthma symptoms limited their activities. Absence from school and work was reported by 58\% of the children and $31 \%$ of adults, respectively.

Conclusions. Asthma control in Latin America falls short of goals in international guidelines, and in many aspects asthma care and control in Latin America suffer from the same shortcomings as in other areas of the world.

Key words Asthma prevention and control; Latin America.

1 Respiratory Medicine Unit, "O. Alassia” Children's Hospital, Santa Fe, Argentina.

2 Pontificia Universidade Catolica Do Rio Grande Do Sul, Brazil.

3 Instituto Nacional De Pediatría, México, D.F., Mexico.

4 Central University of Venezuela, University Hospital of Caracas, Venezuela.
Hospital Nacional Cayetano Heredia, Lima, Peru. 6 Worldwide Epidemiology, GlaxoSmithKline R\&D, Upper Providence, PA, United States of America; and Department of Epidemiology and Population Health, London School of Hygiene and Tropical Medicine, London, United Kingdom.
GlaxoSmithKline Latin America, Miami, Florida, United States. Send correspondence and reprint requests to Daniel Mechali, MD, Director, Medical Affairs, GlaxoSmithKline Latin America, 804 Douglas Road, Suite 461,Coral Gables, Florida 33134, USA; telephone: (305) 529-6970; fax: (305) 446-6991; e-mail: Daniel.G. Mechali@gsk.com 
Asthma is a common and sometimes fatal chronic disease, and its prevalence has been increasing in all regions of the world, especially among children $(1,2)$. The disease represents a significant burden not only in terms of reduced quality of life, but also in terms of healthcare costs. Recent international comparisons of asthma prevalence, particularly those from the European Community Respiratory Health Survey (ECRHS) of asthma prevalence in adults (3), and the International Study of Asthma and Allergies in Childhood (ISAAC) (4), have led to an increased understanding of the worldwide distribution of asthma. Whereas Western Europe has some of the highest prevalence rates of asthma in the world, the ISAAC study found that the prevalence of wheezing is particularly high in English-speaking countries and in some Latin American countries, such as Peru and Costa Rica (3-7).

Guidelines have been developed to promote standardized methods of diagnosis and treatment of asthma. The Global Initiative for Asthma (GINA) established diagnostic and management strategies that are now generally accepted worldwide (1). The Global Initiative guidelines, which were updated in 2002 and 2003, represent a comprehensive plan for managing asthma, with the goal of reducing chronic disability and premature deaths while allowing patients with asthma to lead productive and fulfilling lives. These guidelines specify eight goals for the long-term management of asthma: symptom control, defined as the absence or minimization of chronic symptoms; minimal exacerbations; avoidance of asthmarelated visits to emergency healthcare facilities; minimal or no requirement for quick-relief, short-acting $\beta_{2}$-agonist medication; no asthma-related limitation of normal physical activity; nearnormal lung function as measured by peak expiratory flow (PEF); PEF circadian variation below 20\%; and minimal or no adverse effects from asthma medications (1). Despite this worldwide consensus on the goals of asthma management, recently published epidemiologic data from Europe, the United States of America and Australia indicate that in many countries, the treatment of patients with asthma is inadequate.

Data on the extent of the asthmarelated burden of illness and mortality in Latin America are limited. Although studies have been carried out $(6,8-10)$, they involved relatively small samples of patients selected from a limited number of clinical or other institutional settings, and recent data are not available.

The Asthma Insights and Reality in Latin America (AIRLA) survey was conducted to assess the quality of asthma treatment and control in Latin America by documenting the experience of a wide cross-section of patients with asthma in the community. The AIRLA survey was designed to determine how closely asthma management guidelines are being followed, to assess perception, knowledge and attitudes related to asthma in Latin America, and to assess whether asthma management in countries of the Region meets the goals proposed by the GINA guidelines (1). The AIRLA survey is part of a worldwide research program that has included the Asthma Insights and Reality in Europe (11), the Asthma in America (12), and the Asthma Insights and Reality in Asia-Pacific (13) surveys. As the largest and most comprehensive crossnational survey of children and adults with asthma in Latin America to date, the AIRLA study provides a useful estimate of how well the goals of the GINA guidelines are being met in this region.

\section{METHODS}

\section{Selection of asthma patients}

The AIRLA survey was conducted between May and July 2003 and covered 11 countries: Argentina, Brazil, Chile, Colombia, Costa Rica, Ecuador, Mexico, Paraguay, Peru, Uruguay, and Venezuela. Asthma patients in each country were identified by systematically screening a sample of households for persons who had been diagnosed with asthma. In each of the 11 countries, a sampling plan was designed to provide a nationally representative sample of households that could be screened to identify a community sample of cur- rent asthma sufferers for that country. Sampling and interviewing limitations required that the sampling frame be restricted to urbanized areas within these countries. A geographically-stratified sample of households proportionate to the population was used within these areas.

The survey design required a sample of approximately 400 asthma patients in each of the three largest countries (Argentina, Brazil, and Mexico) and samples of approximately 100 patients in the remaining eight countries. In Argentina, Brazil, and Chile, household interviews were conducted by telephone, whereas in the remaining eight countries the interviews were conducted face-to-face (13) (Table 1).

In each household an adult was asked whether a physician had ever diagnosed any member of the household as having asthma. If the answer was yes, the interviewer asked whether any of these individuals were currently taking medication for their asthma, or had suffered an asthma attack or experienced asthma symptoms in the past year. The number of persons in the household, as well as the number who had been diagnosed with asthma and met the survey criteria for current asthma, was recorded to provide comparative prevalence estimates.

If more than one household member qualified as a current asthma patient, the interviewer randomly selected one as the designated respondent. Only one respondent was interviewed per household because multiple interviews in the same household would have biased the data. If the selected respondent was 16 years of age or older, the interview was conducted with the patient; if the respondent was less than 16 years old, the interview was conducted with the parent or guardian who was most knowledgeable about the child's asthma and treatment.

\section{Data analysis}

A total of 46275 households were screened in the 11 countries, and 2184 adults or children with asthma were identified. 
TABLE 1. Sample strategy and demographic characteristics by country in the Asthma Insights and Reality in Latin America (AIRLA) household asthma survey in 11 Latin American countries in 2003

\begin{tabular}{|c|c|c|c|c|c|c|c|c|c|c|c|c|}
\hline & Argentina & Brazil & Chile & Colombia & $\begin{array}{l}\text { Costa } \\
\text { Rica }\end{array}$ & Ecuador & Mexico & Paraguay & Peru & Uruguay & Venezuela & $\begin{array}{l}\text { AIRLA } \\
\text { total }\end{array}$ \\
\hline \multicolumn{13}{|l|}{ No. of households } \\
\hline Completed sample & 401 & 412 & 100 & 106 & 111 & 90 & 439 & 110 & 100 & 215 & 99 & 2184 \\
\hline \multicolumn{13}{|l|}{ Percent children } \\
\hline$<16$ years of age & 27 & 34 & 31 & 36 & 50 & 49 & 32 & 35 & 53 & 20 & 45 & 37 \\
\hline No. of adults & 293 & 272 & 69 & 68 & 56 & 46 & 298 & 72 & 47 & 172 & 54 & 1376 \\
\hline \multicolumn{13}{|l|}{$\begin{array}{l}\text { Comparative population } \\
\text { prevalence of diagnosed }\end{array}$} \\
\hline $\begin{array}{l}\text { prevalence of diagnosed } \\
\text { current asthma (\%) }\end{array}$ & 2.2 & 2.8 & 3.6 & 2.9 & 6.4 & 1.1 & 1.4 & 2.3 & 2.3 & 4.6 & 7.1 & 2.8 \\
\hline
\end{tabular}

a Telephone interview.

b Face-to-face interview.

Because existing asthma treatment guidelines recommend different management practices for children and adults and responses for children were obtained by proxy, the data on asthma morbidity and asthma management practices were stratified by age (children: below 16 years of age; adults: 16 years of age or over). The frequency and severity of daytime and nighttime symptoms, exercise-induced symptoms and severe episodes, and total symptom frequency, were used to develop a symptom severity index based on the GINA asthma severity scale (Table 2) (1). In addition, events such as hospitalizations and emergency care utilization were documented, as well as the impact in terms of days of school or work lost because of asthma.
All statistical tests were two-sided and a significance level of 0.05 was used.

\section{RESULTS}

\section{Sample population}

From a screening population of 46275 households from the 11 countries (Table 1), a total of 2184 interviews were completed by 1376 adults and by proxy for 808 children. The interviews averaged 30 minutes in length (range 24-51 minutes). Median age of the adults interviewed was 39 years, and median age of the children included in the survey was 8 years. Mean values reported below for adults and children together were calculated from values weighted to reflect the proportion of adults (46\% of 1376$)$ and children $(21 \%$ of 808$)$ in the final sample.

\section{Asthma symptoms and control}

Compared with the GINA criteria, asthma was poorly controlled in a high proportion of respondents (Table 3). Overall, only $2.4 \%$ of all patients (2.3\% adults and $2.6 \%$ children) met all the GINA criteria for total asthma control. Daytime coughing, wheezing, shortness of breath or chest tightness during the previous 4 weeks were reported by $56 \%$ of all respondents $(56 \%$ of adults and $57 \%$ of children), and $51 \%$ (54\% of adults and $47 \%$ of chil-

TABLE 2. Symptom severity index developed according to frequency and severity of asthma symptoms (cough, wheeze, shortness of breath or chest tightness) surveyed in 11 Latin American countries in 2003

\begin{tabular}{|c|c|c|c|c|}
\hline $\begin{array}{c}\text { Frequency of } \\
\text { asthma symptoms }\end{array}$ & $\begin{array}{c}\text { Severe } \\
\text { persistent }\end{array}$ & $\begin{array}{l}\text { Moderate } \\
\text { persistent }\end{array}$ & $\begin{array}{l}\text { Mild } \\
\text { persistent }\end{array}$ & Intermittent \\
\hline $\begin{array}{l}\text { Daytime symptoms in } \\
\text { the past } 4 \text { weeks }\end{array}$ & 3 times/day & $\begin{array}{l}\text { Every day } \\
\text { ( } \leq \text { twice/day) }\end{array}$ & $\begin{array}{l}\text { At least } \\
\text { twice/week }\end{array}$ & $\begin{array}{l}\text { Less than } \\
\text { twice/week }\end{array}$ \\
\hline $\begin{array}{l}\text { Night-time symptoms in } \\
\text { the past } 4 \text { weeks }\end{array}$ & $\begin{array}{l}\text { Every day/ } \\
\text { most days }\end{array}$ & $\begin{array}{l}\text { At least } \\
\text { twice/week }\end{array}$ & $\begin{array}{l}\text { At least } \\
\text { twice/month }\end{array}$ & $\begin{array}{l}\text { Less than } \\
\text { twice/month }\end{array}$ \\
\hline $\begin{array}{l}\text { Severe episodes in } \\
\text { the past } 12 \text { months }\end{array}$ & - & Every day & $\begin{array}{l}\text { At least } \\
\text { twice/week }\end{array}$ & $\begin{array}{l}\text { Once a week } \\
\text { or less }\end{array}$ \\
\hline $\begin{array}{l}\text { Exercise-induced symptoms } \\
\text { in the past } 12 \text { months }\end{array}$ & - & Every day & $\begin{array}{l}\text { At least } \\
\text { twice/week }\end{array}$ & $\begin{array}{l}\text { Once a week } \\
\text { or less }\end{array}$ \\
\hline During a typical week & 21 times/week & 7-20 times/week & 3-6 times/week & Twice/week or less \\
\hline
\end{tabular}


TABLE 3. The Global Initiative for Asthma (GINA) recommendations and results of the Asthma Insights and Reality in Latin America (AIRLA) survey in 11 Latin American countries in 2003

\begin{tabular}{|c|c|c|c|}
\hline GINA definition for control of asthma & AIRLA findings & $\begin{array}{l}\text { Adults } \\
\%\end{array}$ & $\begin{array}{l}\text { Children } \\
\%\end{array}$ \\
\hline $\begin{array}{l}\text { Minimal (ideally no) chronic symptoms, } \\
\text { including nocturnal symptoms }\end{array}$ & $\begin{array}{l}\text { Asthma symptoms: } \\
\text { - During day (past } 4 \text { weeks) } \\
\text { - Night wakening (past } 4 \text { weeks) } \\
\text { - Exercise-induced asthma (past } \\
12 \text { months) }\end{array}$ & $\begin{array}{l}56 \\
54 \\
41\end{array}$ & $\begin{array}{l}57 \\
47 \\
37\end{array}$ \\
\hline Minimal exacerbation & Sleep disruption at least once per week & 39 & 34 \\
\hline No emergency visit for asthma & $\begin{array}{l}\text { Use of emergency care in past } 12 \\
\text { months: hospitalization, emergency } \\
\text { service visit and unscheduled } \\
\text { emergency visits }\end{array}$ & 52 & 69 \\
\hline $\begin{array}{l}\text { Minimal need for short-acting } \beta_{2}- \\
\text { agonists }\end{array}$ & $\begin{array}{l}\text { Current use of quick-relief } \\
\text { bronchodilators }^{\mathrm{a}}\end{array}$ & 55 & 61 \\
\hline $\begin{array}{l}\text { No limitation on activities, including } \\
\text { exercise }\end{array}$ & $\begin{array}{l}\text { Asthma restricts: } \\
\text { - Sports and recreation } \\
\text { - Normal physical activity } \\
\text { - Choice of jobs or careers (adults) } \\
\text { - Social activities } \\
\text { - Sleeping } \\
\text { - Lifestyle } \\
\text { - Household chores } \\
\text { - Any of the above }\end{array}$ & $\begin{array}{l}55 \\
46 \\
30 \\
31 \\
48 \\
39 \\
46 \\
79\end{array}$ & $\begin{array}{r}42 \\
33 \\
- \\
24 \\
43 \\
33 \\
21 \\
68\end{array}$ \\
\hline $\begin{array}{l}\text { Normal or near-normal lung function } \\
\left(\mathrm{PEF}^{\mathrm{b}} \text { variability }<20 \%\right)\end{array}$ & Never had a lung-function test & 49 & 62 \\
\hline
\end{tabular}

${ }^{a}$ Includes short-acting $\beta_{2}$-agonists (inhaled and oral) and anticholinergics.

${ }^{b} \mathrm{PEF}=$ peak expiratory flow.

dren) had been awakened by their asthma symptoms. Sleep disruption, a marker of suboptimal asthma treatment, occurred at least once per week in $39 \%$ of the adults and $34 \%$ of the children and every night in $9 \%$ of the adults and $6 \%$ of the children. In all, more than half of asthma patients in this survey ( $52 \%$ of the adults, $69 \%$ of the children, weighted mean 58\%) had been hospitalized, gone to a hospital emergency service, or made other unscheduled emergency visits to healthcare services for their asthma in the past 12 months (Table 3 ).

\section{Perceived asthma severity and symptom control}

When questioned about the severity of their asthma during the past 4 weeks, $27 \%$ of the respondents said they had no asthma at all and $44 \%$ said they had mild asthma, whereas only
$6 \%$ considered themselves to have had severe asthma. In reality, based on the GINA symptom severity index, $21 \%$ of the patients had had severe persistent symptoms. The rate of underestimation of asthma severity was similar in adults and children. Respondents also perceived their asthma to be better controlled than their clinical symp- toms suggested, and almost one-half of the respondents (44.7\%) with severe persistent asthma thought their disease was well or completely controlled (Table 4).

Activity limitation caused by asthma was considerable: most adults $(79 \%)$ and children (68\%) reported that their asthma symptoms limited their daily activities in some way. Specifically, asthma sufferers reported activity limitation in sports and recreation $(50 \%)$, normal physical activity $(41 \%)$, lifestyle $(37 \%)$, social activities $(29 \%)$, choice of jobs or careers $(30 \%$, adults only), sleeping (46\%) and household chores (37\%) (Table 3). In addition, $31 \%$ of the adults and $58 \%$ of the children with asthma in this study reported that their asthma had caused them to miss work or school in the last year.

\section{Use of medication in asthma management}

All respondents were asked what kinds of medicines they had used to reduce or prevent airway inflammation in the past 4 weeks. The majority had used either prescription $(54 \%)$ or over-the-counter medicines $(16 \%)$ for quick relief from asthma symptoms. In all, $37 \%$ of the people with asthma reported they were being treated with prescription medication to reduce or prevent airway inflammation, but only $6 \%$ (calculated as the mean of values weighted for each degree of symptom severity) of asthma patients in this

TABLE 4. Symptom severity index by self-classification of asthma control according to the Asthma Insights and Reality in Latin America (AIRLA) household asthma survey in 11 Latin American countries, 2003

\begin{tabular}{lccccc}
\hline & \multicolumn{5}{c}{ Current symptom severity index } \\
\cline { 2 - 6 } \multicolumn{1}{c}{$\begin{array}{c}\text { Patient } \\
\text { self-classification }\end{array}$} & $\begin{array}{c}\text { Severe } \\
\text { persistent } \\
\text { (No. }=475)\end{array}$ & $\begin{array}{c}\text { Moderate } \\
\text { persistent } \\
\text { (No. }=214)\end{array}$ & $\begin{array}{c}\text { Mild } \\
\text { persistent } \\
(\text { No. }=474)\end{array}$ & $\begin{array}{c}\text { All grades } \\
\text { persistent } \\
\text { (No. = 1 163) }\end{array}$ & $\begin{array}{c}\text { Intermittent } \\
(\text { No. }=1021)\end{array}$ \\
\hline Completely controlled (\%) & 4.7 & 15.0 & 6.4 & 8.7 & 30.4 \\
Well controlled (\%) & 40.0 & 50.3 & 45.4 & 45.3 & 52.3 \\
Somewhat controlled (\%) & 34.4 & 29.9 & 38.7 & 34.3 & 15.0 \\
Poorly controlled (\%) & 13.6 & 3.5 & 7.6 & 8.2 & 1.6 \\
Not controlled at all (\%) & 7.3 & 1.2 & 1.9 & 3.5 & 0.6 \\
\hline
\end{tabular}


FIGURE 1. Summary of asthma medication use according to asthma severity in adults and children surveyed in 11 Latin American countries in 2003. Values are weighted means for adults and children combined

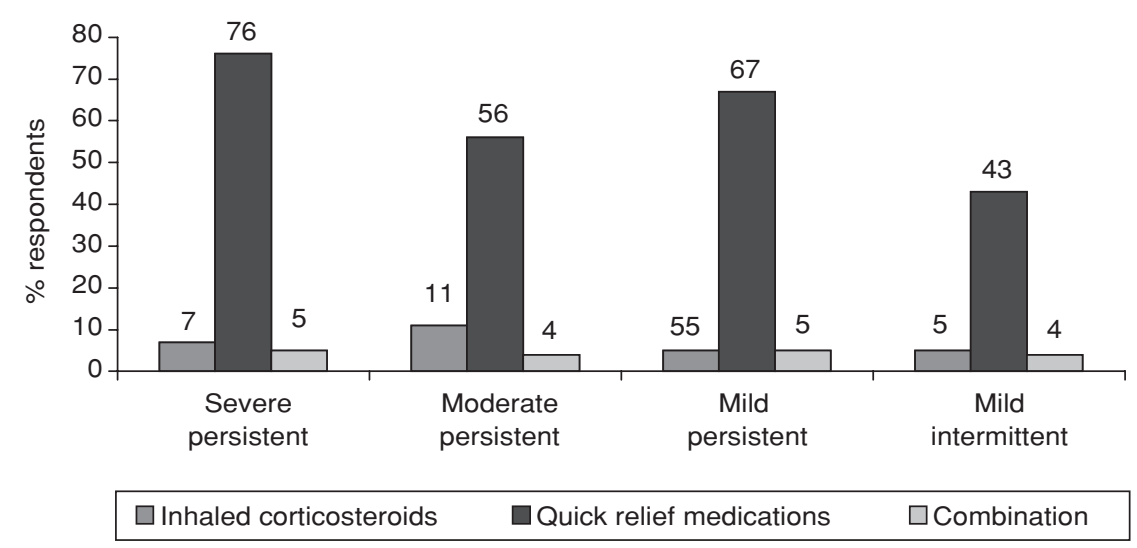

survey used inhaled corticosteroids (Figure 1). In persons with persistent asthma there was no trend toward increased use of inhaled corticosteroids with increasing severity from mild-tomoderate to severe persistent asthma.

\section{Monitoring asthma}

Figure 2 shows our findings for the different methods available to improve lung function in the management of asthma. In this survey only
$51 \%$ of the adults and $38 \%$ of the children had ever been given a lung function test, and only two thirds of them reported being given a lung function test in the past year. Only 23\% of the adults and $18 \%$ of the children had ever heard of a peak flow meter, and only $4 \%$ of the adults and $3 \%$ of the children had one. Another cornerstone of asthma management, a written action plan by the treating physician, was given to two out of every five patients $(38 \%$ of the adults, $49 \%$ of the children).
FIGURE 2. Summary of methods used to monitor and manage asthma in adults and children surveyed in 11 Latin American countries in 2003. Values are weighted means for adults and children combined

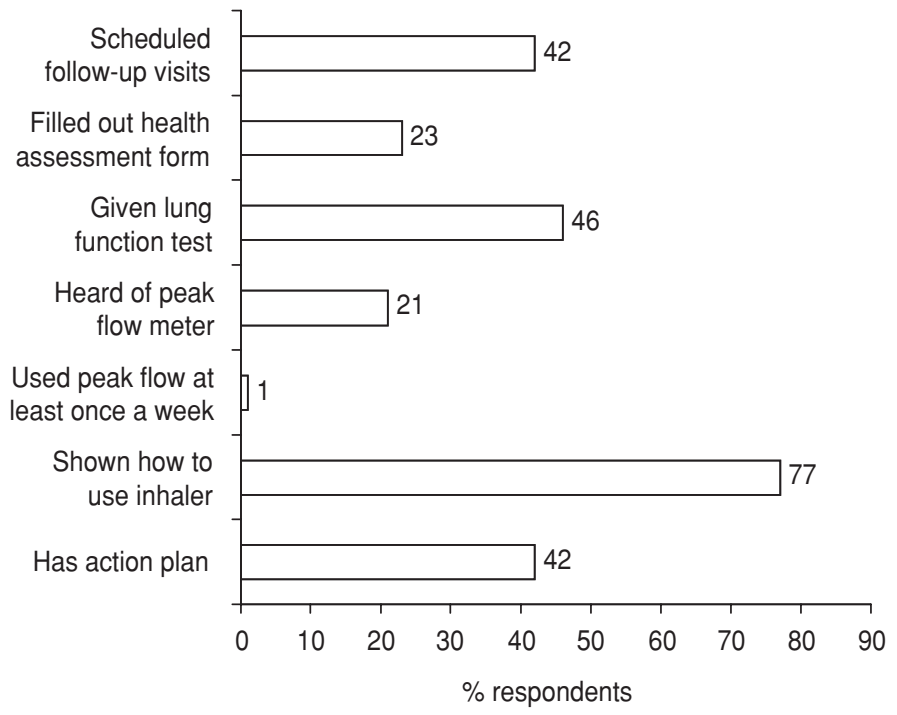

\section{Knowledge and understanding of asthma}

Patients were asked in an openended question what they thought was the underlying condition that causes asthma symptoms. The most common responses were allergies (42\%) and bronchospasms (17\%). One in six persons with asthma (15\%) said they did not know the underlying condition that causes asthma symptoms, and $16 \%$ gave the correct answer that "inflammation of the airways" is the underlying condition. When the information was again requested in the form of an aided question, a minority of respondents (45\%) replied that they had heard that inflammation was the underlying cause of asthma.

When asked about their expectations concerning the ability of treatment to affect asthma, 50\% of the adults said the underlying condition for asthma could be treated; $40 \%$ said only the symptoms could be treated, not the underlying condition; the remainder were unsure. In all, $91 \%$ of the respondents thought there was a clear need for better education of people with asthma about their condition and its treatment.

\section{DISCUSSION}

The AIRLA survey is the first comprehensive survey of the current state of asthma management in Latin America. The survey findings indicate that the current levels of asthma control in this region fall far short of the goals for long-term asthma management established by GINA, and in many aspects of asthma care and control, Latin America lags behind other areas of the world. Asthma morbidity is high, with an unacceptably high reliance on the use of emergency care or rescue care. Overall, only $2.4 \%$ of all patients surveyed met all the GINA criteria for total asthma control. The most likely reasons for this are not only the underrecognition of uncontrolled asthma, underuse of appropriate controller treatment, and inadequate patient education and lung function monitoring, 
but also patient denial and reduced patient expectations for quality of life. The survey suggests that such issues will need to be addressed in Latin America before the aims of achieving and maintaining asthma control, and reducing the burden of this disease, can be realized.

For example, despite the fact that one of the GINA goals is minimal or no symptoms of asthma, more than half $(56 \%)$ of the persons in our survey reported that they had daytime symptoms at least once a week, and $45 \%$ were awakened by symptoms at night at least once a week. Although the GINA goal is no emergency visits to doctors or hospitals, more than half of the people with asthma in this Latin American survey had been hospitalized or had used emergency care because of asthma in the past 12 months. The rate of hospitalization in the past year $(22 \%)$ was far higher than in the Asia-Pacific (AIRIAP) survey (15\%) (13), the European (AIRE) survey (7\%) (11) or the Asthma in America survey (9\%) (12).

The GINA goals for asthma management include minimal need for quick-relief $\beta_{2}$-agonist therapy. In AIRLA, $54 \%$ of the people with asthma had used prescription quick-relief medicines for their asthma in the previous 4 weeks. Most who used inhalers for quick relief reported that they had used them daily in the previous 4 weeks. Moreover, although GINA has set a goal of no limitations on physical activities and exercise, $79 \%$ of the adults and $68 \%$ of the children with asthma in this Latin American sample reported that their asthma symptoms limited their daily activities in some way (Table 3).

The AIRLA survey suggests several factors that may contribute to the gap between the goals for asthma management and reality in Latin America. The rate of diagnosis and appropriate management of asthma is low, and monitoring of the patients' condition and treatment by doctors or by the patients themselves is insufficient. The use of inhaled corticosteroids or controller therapy is very low. This is consistent with published reports from elsewhere in the world that adherence to asthma treatment guidelines is generally poor $(11,12,14-17)$. Both underprescribing by doctors $(14,16,18)$ and poor compliance with prescribed medications by patients (19) have been implicated in suboptimal asthma management. A recent survey of respiratory physicians from five European countries reported that although they accepted the recommendations in asthma guidelines, only a small proportion of patients were treated according to the guidelines (20). Failure to follow asthma management guidelines may result in poor asthma control for many patients.

Another key area that needs to be addressed is patient education. Patients should be educated about the causes of asthma, what triggers the condition, how it should be monitored and managed and, importantly, the outcomes that can be expected and when to recognize lack of asthma control. Many patients are unaware of the underlying cause of asthma, and almost half believe that only the symptoms can be treated, not the underlying condition.

One factor that may contribute to the underrecognition and undertreatment of asthma is that patients tend to deny the severity of their symptoms and to overestimate their current degree of symptom control. Nearly half of the patients in the AIRLA survey whose symptoms indicate severe persistent asthma said their asthma was well or completely controlled, probably because they did not know any better.
This unsatisfactory situation may change in the near future as a large recent trial (21) indicates that complete control of asthma, equivalent to clinical remission of the disease, is achievable. In this study, sustained use of a combination of the long-acting $\beta_{2}$-agonist salmeterol and the inhaled corticosteroid fluticasone propionate enabled significantly more patients to achieve total control of their asthma, as defined by the international guidelines, than did use of the corticosteroid alone.

The urban sampling frame used in most countries and the use of telephone surveys in a few countries undoubtedly create selection bias toward higher socioeconomic levels. In the absence of comprehensive demographic information, it is hard to assess the magnitude of this bias. Previous research has demonstrated that the American Thoracic Society questionnaire is a valid tool for the measurement of asthma symptoms in the general population and is highly reliable when administered by telephone (22).

In summary, the AIRLA survey documents an unacceptably high level of patient morbidity from asthma throughout Latin America. The vast majority of patients were not receiving appropriate diagnosis, therapy and monitoring, and were failing to achieve the goals for asthma management set out in the GINA guidelines. This places a great burden on the healthcare system and society as a whole, with substantial loss of time from work and school. However, it is important to realize that this morbidity is largely preventable. Steps therefore need to be taken to educate doctors and patients that, by following an asthma management strategy to achieve and maintain control of the disease, more patients can achieve control of their asthma and avoid many of the constraints imposed by their disease.

\section{REFERENCES}

1. Global Initiative for Asthma (GINA). Global Strategy for Asthma Management and Prevention. NHLBI/WHO Workshop Report.
Bethesda, MD: National Institutes of Health National Heart, Lung and Blood Institute; 2002. (NIH Publication No. 02-3659).
2. Beasley R, Crane J, Lai CKW, Pearce N. Prevalence and aetiology of asthma. J Allergy Clin Immunol. 2000;105:S466-72. 
3. European Community Respiratory Health Survey. Variations in the prevalence of respiratory symptoms, self-reported asthma attacks, and use of asthma medication in the European Community Respiratory Health Survey (ECRHS). Eur Respir J. 1996;9:687-95.

4. The International Study of Asthma and Allergies in Childhood (ISAAC) Steering Committee. Worldwide variations in the prevalence of asthma symptoms: The International Study of Asthma and Allergies in Childhood (ISAAC). Eur Respir J. 1998;12:315-35.

5. Mallol J, Clayton T, Asher I, Williams H, Beasley R, on behalf of the ISAAC Steering Committee. ISAAC findings in children aged 13-14 years: an overview. ACI Int. 1999;11: 176-82.

6. Mallol J, Sole D, Asher I, Clayton T, Stein R, Soto-Quiroz M. Prevalence of asthma symptoms in Latin America: the International Study of Asthma and Allergies in Childhood (ISAAC). Pediatr Pulmonol. 2000;30:439-44.

7. Smyth R L. Asthma: a major pediatric issue. Resp Res. 2002;3(Suppl. 1): S3-7.

8. Neffen H, Baena-Cagnani CE, Malka S, Sole D, Sepúlveda R, Caraballo L, et al. Asthma mortality in Latin America. J Investig Allergol Clin Immunol. 1997;7:249-53.

9. Vergara C, Caraballo L. Asthma mortality in Colombia. Ann Allergy Asthma Immunol. 1998;80:55-60.

10. Chatkin JM, Barreto SM, Fonseca NA, Sears $M$. Trends in asthma mortality in young people in southern Brazil. Ann Allergy Asthma Immunol. 1999;82:287-92.
11. Rabe KF, Vermeire PA, Soriano JB, Maier WC. Clinical management of asthma in 1999: the Asthma Insights and Reality in Europe (AIRE) study. Eur Respir J. 2000;16:802-7.

12. Adams RJ, Fuhlbrigge A, Guilbert T, Lozano $\mathrm{P}$, Martinez F. Inadequate use of asthma medication in the United States: results of the Asthma in America national population survey. J Allergy Clin Immunol. 2002;110;58-64.

13. Lai CWK, de Guia TS, Kim Y-Y, Kuo S-H, Mukhopadhyay A, Soriano J B, et al. Asthma control in the Asia-Pacific region: the Asthma Insights and Reality in Asia-Pacific Study. J Allergy Clin Immunol. 2003;111:263-8.

14. Bousquet J, Knani J, Henry C, Liard R, Richard A, Michel FB, et al. Undertreatment in a non-selected population of adult patients with asthma. J Allergy Clin Immunol. 1996;98: 514-21.

15. Legorreta AP, Christian-Herman I, O'Connor RD, Hasan MM, Evans R, Leung KM. Compliance with national asthma management guidelines and specialty care: a health maintenance organization experience. Arch Intern Med. 1998;158:457-64.

16. Taylor DM, Auble TE, Calhoun WJ, Mosesso VN. Current outpatient management of asthma shows poor compliance with international consensus guidelines. Chest. 1999;116: 1638-45.

17. Nicklas RA. National and international guidelines for the diagnosis and treatment of asthma. Curr Opin Pulm Med. 1997;3:51-5.

18. Enright PL, McClelland RL, Newman AB, Gottlieb DJ, Lebowitz MD, for the Cardiovas- cular Health Study Research Group. Underdiagnosis and undertreatment of asthma in the elderly. Chest. 1999;116:603-13.

19. Reid D, Abramson M, Raven J, Walters HE. Management and treatment perceptions among young adults with asthma in Melbourne: the Australian experience from the European Community Respiratory Health Survey. Respirology. 2000;5:281-7.

20. Lagerlov $P$, Veninga CC, Muskova $M$, Hummers-Pradier E, Stalsby Lundborg C, Andrew M, et al., on behalf of the Drug Evaluation Project (DEP) group. Asthma management in five European countries: doctors knowledge, attitudes and prescribing behaviour. Eur Respir J. 2000;15:25-9.

21. Bateman ED, Boushey HA, Bousquet J, Busse WW, Clark TJH, Pauwels RA, Pedersen SE, for the GOAL Investigators Group. Can guideline-defined asthma control be achieved? The Gaining Optimal Asthma Control Study. Am J Respir Crit Care Med. 2004; 170:836-44.

22. Galobardes B, Sunyer J, Anto JM, Castellsague J, Soriano JB, Tobias A. Effect of the method of administration, mail or telephone, on the validity and reliability of a respiratory health questionnaire. J Clin Epidemiol. 1998;51: $875-81$.

Manuscript received on 28 June 2004. Revised version accepted for publication on 7 January 2005.

RESUMEN Objetivos. Los objetivos de esta encuesta fueron 1) determinar la calidad del tratamiento y control del asma en América Latina, 2) determinar el grado de adherencia a las guías de tratamiento, y 3) determinar la percepción, los conocimientos y las actitudes con respecto al asma en América Latina.

El control del asma en América Latina: la encuesta de Percepción y Realidad del Asma en América Latina

Método. La encuesta se realizó en una muestra de hogares donde se entrevistó a 2184 adultos asmáticos o padres de niños con asma en 11 países de América Latina. Se obtuvo información sobre la utilización de los recursos del sistema de salud, la gravedad de los síntomas, la limitación de actividades y el uso de medicamentos.

Resultados. El 56\% de los encuestados refirió síntomas diurnos, y 51\% mencionaron despertarse por la noche debido al asma. Más de la mitad habían sido hospitalizados o atendidos en salas de urgencia hospitalarias, o habían realizado consultas no programadas a cualquier otro nivel del sistema sanitario. La percepción del control del asma por parte de los pacientes no se corresponde con la gravedad de los síntomas, incluso en aquellos pacientes con asma persistente, ya que $44,7 \%$ de estos consideraban que el control de su enfermedad era bueno o total. Solo $2,4 \%$ de los pacientes (2,3\% de los adultos y 2,6\% de los niños) cumplían todos los criterios correspondientes a un control total del asma. Aunque 37\% de los participantes refirieron haber sido tratados con algún medicamento adquirible por receta médica, solamente $6 \%$ utilizaban corticoesteroides inhalados. El 79\% de los pacientes adultos y $68 \%$ de los niños con asma mencionaron que sus síntomas limitaban sus actividades de alguna manera. El 58\% de los niños habían faltado al colegio, y $31 \%$ de los adultos habían faltado al trabajo debido al asma.

Conclusiones. Los niveles actuales de control del asma en América Latina distan mucho de los objetivos especificados por las guías internacionales para el manejo del asma, y en muchos aspectos referidos al cuidado y al control de la enfermedad se observan en América Latina las mismas carencias que en otras áreas del mundo.

\section{Palabras clave: Asma, prevención y control; América Latina.}

